\title{
Thermodynamic Feasibility of Pure Hydrogen Production and Storage in Iron and Germanium Based Double Chemical Looping Process
}

\author{
Grzegorz Stowiński and Adam Smoliński*,b \\ ${ }^{a}$ Computer Engineering, Vistula University, 3 Stoktosy Str., 02-787 Warsaw, Poland \\ ${ }^{b}$ Department of Energy Saving and Air Protection, Central Mining Institute, Plac Gwarkow 1, \\ 40-166 Katowice, Poland
}

\begin{abstract}
Solid iron based low or medium temperature chemical loop is considered as a possible option of hydrogen storage and production. In the method, hydrogen is produced via iron oxidation with steam, and in the next phase iron oxide is reduced with hydrogen, synthesis gas or methane. In the reduction stage the reaction is terminated when the atmosphere still contains a large fraction of the reducing agent (often over 70 vol.\%). In the paper the innovative idea of a double, iron and germanium based, chemical cycle was proposed. The thermodynamic calculations show that the reduction stage in the double iron-germanium cycle is more effective than the classical iron based loop.
\end{abstract}

Keywords: hydrogen storage, hydrogen production, steam-iron process, chemical loop, thermodynamics

\section{Introduction}

The wide implementation of the hydrogen economy requires the development of reliable and cost-effective techniques of hydrogen storage and production. ${ }^{1,2}$ Iron and iron oxides may be potentially applied in the process of hydrogen production and storage, respectively. ${ }^{3-6}$ The main steps of the process may be presented as follows:

$\mathrm{Fe}+\mathrm{H}_{2} \mathrm{O}=\mathrm{FeO}+\mathrm{H}_{2}$

$\mathrm{FeO}+\mathrm{C}=\mathrm{Fe}+\mathrm{CO}$

In the first step of the process discussed, molten iron reacts with steam and hydrogen is produced (see equation 1). Then wustite $(\mathrm{FeO})$ is reduced with carbon (see equation 2 ). The recovered iron is recycled to the first stage of the process.

Although the hydrogen production in steam-iron process has been known since the $19^{\text {th }}$ century, it is considered to be uneconomical nowadays in comparison with hydrogen production in the process of natural gas reforming. At the Ohio State University the innovative method of natural gas conversion with the application of a technology employing the chemical looping was proposed. In this option the iron based oxygen carrier and a novel gas-solid counter-current

\footnotetext{
*e-mail: asmolinski@gig.katowice.pl
}

moving bed reactor for hydrogen production was proposed. ${ }^{7}$ The idea of hydrogen production in steam-iron process has been previously proposed by Alchemix, as the Hydromax process, where the steam-iron stage is performed in a bath of $25 \%$ of iron and $75 \%$ of tin, which enables decrease in the operation temperature to about $1250{ }^{\circ} \mathrm{C}$, resulting in a significantly improved process economics. ${ }^{8}$

Another technological option presented in the literature ${ }^{9}$ comprises in performing the steam-iron process in a solid phase at the temperatures below $1000{ }^{\circ} \mathrm{C}$. This low-temperature steam-iron process (LTSI) may be potentially applied in hydrogen production and/or storage. In the first stage of the process iron reacts with steam to form hydrogen and magnetite (the temperatures applied are more thermodynamically favorable for magnetite formation than for wustite):

$0.75 \mathrm{Fe}+\mathrm{H}_{2} \mathrm{O}=0.25 \mathrm{Fe}_{3} \mathrm{O}_{4}+\mathrm{H}_{2}$

In the next stage magnetite may be reduced with methane (see equation 4 ) or hydrogen (reversed equation 3 ):

$\mathrm{Fe}_{3} \mathrm{O}_{4}+\mathrm{CH}_{4}=3 \mathrm{Fe}+\mathrm{CO}_{2}+2 \mathrm{H}_{2} \mathrm{O}$

The process of magnetite reduction with hydrogen may be applicable in hydrogen storage. The same process 
utilizing other reducing agents, like e.g. methane or syngas, could be employed in hydrogen production. The main operational issue of the LTSI process reported in the literature $^{9-13}$ is the deterioration of iron bed performance, resulting from sintering, carbon deposition and $\mathrm{Fe}_{3} \mathrm{C}$ formation, when carbon-containing fuels are utilized in the magnetite reduction stage. Another problem is low reaction rate at lower temperatures. The effects of sintering and the influence of iron doping on bed performance is widely discussed in the literature. ${ }^{11,14-17}$ Doping agents, such as aluminum, molybdenum and cerium are reported to mitigate the sintering effect. Weak stabilizing effect was also observed for scandium, titanium, vanadium, chromium, yttrium and zirconium. Noble metals, like ruthenium, rhodium, palladium, silver and iridium expose a catalytic activity, and enhance the process kinetics. Platinum was also tested, but no reduction of the sintering effect was observed with its applications. Additions of manganese, cobalt, nickel, copper, zinc, gallium, niobium, tungsten, and rhenium have been reported to enhance the sintering. Also the thermodynamic constraints of the reduction stage have been reported among the main difficulties of the process discussed; magnetite reduction terminates when the atmosphere still contains considerable amounts of the reducing gas $\left(\mathrm{H}_{2}\right.$, syngas $){ }^{18}$ This implies the need for a more advanced gas management system, which is disadvantageous in terms of the technological simplicity and process economics. The evaluation of the application of iron as a potential material for hydrogen storage or hydrogen production from carbonaceous materials reveals that the reduction stage of the iron cycle is quite problematic. The utilization of the reducing gases: $\mathrm{H}_{2}, \mathrm{CO}$ and $\mathrm{CH}_{4}$ is weak. Furthermore, there is a possibility of disadvantageous phenomena, like carbon deposition, $\mathrm{Fe}_{3} \mathrm{C}$ formation, etc. ${ }^{18}$ The poor thermodynamics of the reduction stage in the iron cycle was a stimulus for searching other materials with better potential performance, such as germanium.

In the paper the idea of a double chemical loop, comprising of $\mathrm{Fe}-\mathrm{Fe}_{3} \mathrm{O}_{4}$ and $\mathrm{Ge}-\mathrm{GeO}_{2}$ loops, potentially enabling avoidance of the above mentioned constraints is presented. The thermodynamic calculations, proving a modest improvement in the $\mathrm{Fe}-\mathrm{Ge}$ loop in comparison with the iron cycle are given, since they constitute the first step of the feasibility assessment of any chemical process. ${ }^{18}$ The kinetic limitations, inefficiency in the reduction stages, sintering and carbon deposition issues, gas management aspects, and considerations regarding the reactor design all remain significant concerns in terms of the practical implementation. The additional cost and complexity would also clearly be involved in the double chemical looping process. Taking into account all these limitations, the main objective of the study is therefore to supplement the currently available thermodynamic databases of chemical cycles for hydrogen production and storage, since the double Fe-Ge chemical looping process is considered to significantly improve hydrogen production in comparison with the classical iron cycle.

\section{Experimental}

The combination of $\mathrm{Fe}-\mathrm{Fe}_{3} \mathrm{O}_{4}$ loop with $\mathrm{Ge}-\mathrm{GeO}_{2}$ loop may improve gas management in the reduction stage of the cycle. Germanium shows lower affinity to oxygen than iron, and thus may be reduced with the flue gas from magnetite reduction.

\section{Germanium based loop}

Germanium melting point temperature is $937^{\circ} \mathrm{C}$, while germanium dioxide melting point is $1115^{\circ} \mathrm{C}$, which implies that $\mathrm{Ge}-\mathrm{GeO}_{2}$ loop could be applied at temperatures of up to $800{ }^{\circ} \mathrm{C}$.

\section{Germanium oxidation with steam}

Hydrogen is produced in the reaction of germanium oxidation with steam.

$0.5 \mathrm{Ge}+\mathrm{H}_{2} \mathrm{O}=0.5 \mathrm{GeO}_{2}+\mathrm{H}_{2}$

Figure 1 shows the phase stability diagram for such a system. As it can be seen from Figure 1, temperatures below $600{ }^{\circ} \mathrm{C}$ may be used for generation of concentrated hydrogen stream. The maximum concentration of hydrogen achievable in Ge oxidation decreases from nearly $100 \mathrm{vol} . \%$ at low temperatures to $56 \mathrm{vol} . \%$ at $800{ }^{\circ} \mathrm{C}$.

\section{Germanium dioxide reduction with hydrogen}

Germanium dioxide reduction with hydrogen proceeds by a reversed reaction given in equation 5 . As it can be seen from Figure 1, the reduction should be performed at temperatures above $600{ }^{\circ} \mathrm{C}$.

\section{Germanium dioxide reduction with carbon monoxide}

Germanium dioxide reduction with carbon monoxide may be described as follows:

$0.5 \mathrm{GeO}_{2}+\mathrm{CO}=0.5 \mathrm{Ge}+\mathrm{CO}_{2}$ 


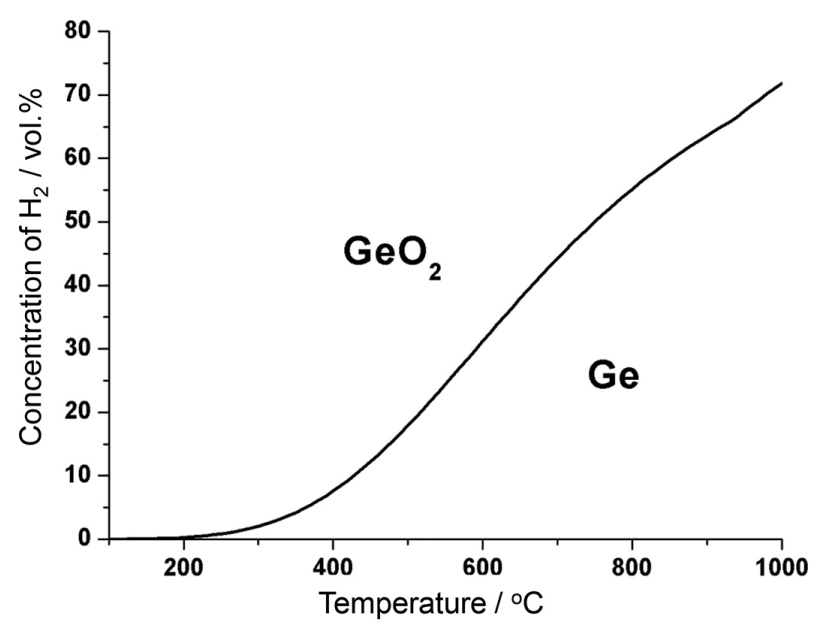

Figure 1. The phase stability diagram of $\mathrm{Ge}$ and $\mathrm{GeO}_{2}$ phases in the $\mathrm{H}_{2} \mathrm{O}-\mathrm{H}_{2}$ atmosphere.

The phase stability diagram for this system is given in Figure 2. It can be seen that the maximum concentration of carbon dioxide grows from 30 vol. $\%$ at $100{ }^{\circ} \mathrm{C}$ to nearly 58 vol. $\%$ at $800{ }^{\circ} \mathrm{C}$. Thus, high temperatures $\left(600-800^{\circ} \mathrm{C}\right)$ are more favorable for $\mathrm{GeO}_{2}$ reduction with carbon monoxide.

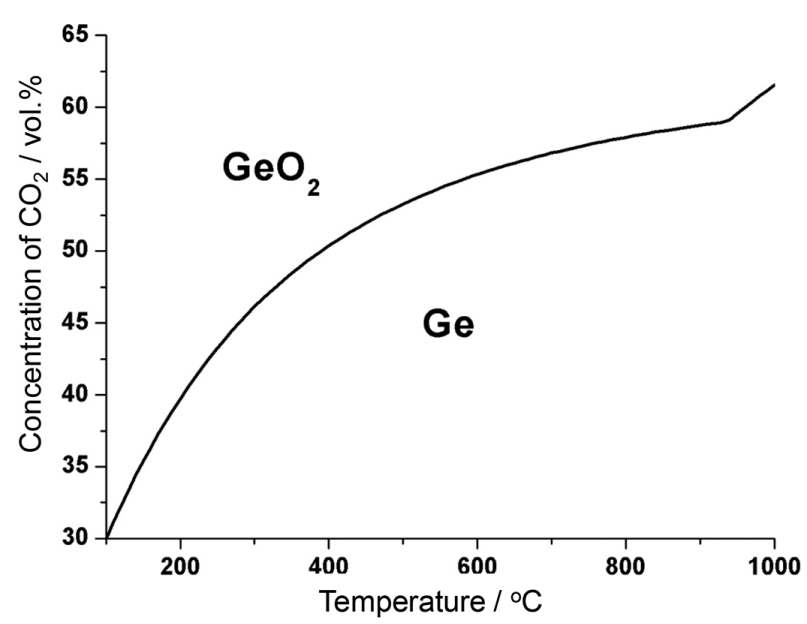

Figure 2. The phase stability diagram of $\mathrm{Ge}$ and $\mathrm{GeO}_{2}$ in the $\mathrm{CO}_{2}-\mathrm{CO}$ atmosphere.

\section{Germanium dioxide reduction with methane}

It is assumed that the reduction of germanium dioxide with methane proceeds as follows:

$2 \mathrm{GeO}_{2}+\mathrm{CH}_{4}=2 \mathrm{Ge}+\mathrm{CO}_{2}+2 \mathrm{H}_{2} \mathrm{O}$

The phase stability diagram of $\mathrm{Ge}$ and $\mathrm{GeO}_{2}$ in $\mathrm{CH}_{4}$, $\mathrm{CO}_{2}$ and $\mathrm{H}_{2} \mathrm{O}$ atmosphere is presented in Figure 3. In the temperature range of $400-800{ }^{\circ} \mathrm{C}$, the equilibrium concentration of methane decreases strongly with the temperature increase; high temperature needs to be applied

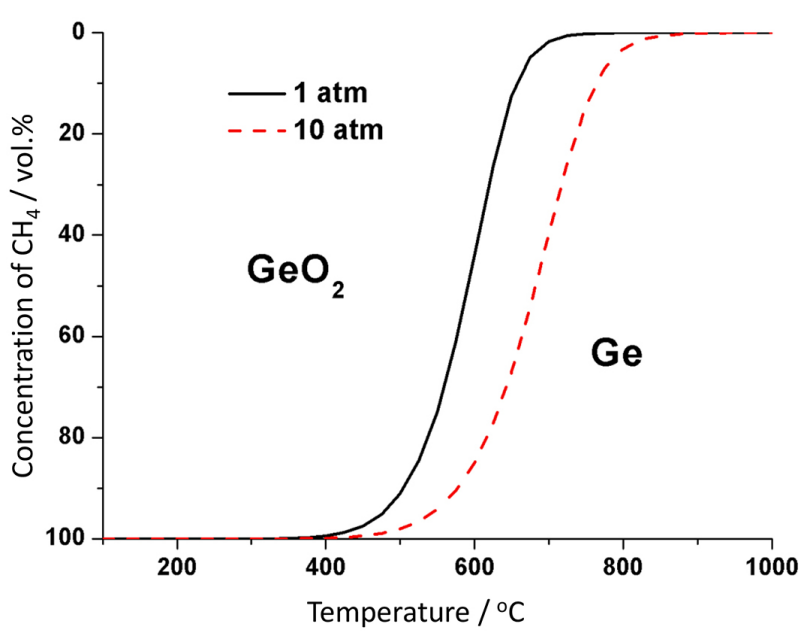

Figure 3. The phase stability diagram of $\mathrm{Ge}$ and $\mathrm{GeO}_{2}$ in the $\mathrm{CH}_{4}$ atmosphere.

to achieve a satisfactory efficiency of methane consumption. The rise in pressure also increases the temperature of the phase stability border.

\section{Results and Discussion}

The compound used in a cycle as a gas carrier may be in a liquid state, like in case of high temperature $\mathrm{Fe}-\mathrm{FeO}$ cycle or nitrite-nitrate cycle, or in the solid state. Depending on the aggregation state, the cycle application is connected with different technical and material issues. Liquid state cycles are probably more convenient for larger industrial applications as they allow for potentially better reaction kinetics since the mass transport is easier in a liquid phase. Additionally, mass transport can be improved by stirring the bath of molten carrier. The liquid phase, however, is problematic mainly due to corrosive impact on container materials used. In case of solid state oxygen carriers the kinetics of the reactions is also dependent on the quality of the porous structure of the material, influencing the availability of the contact area. In the literature ${ }^{4,6,18}$ numerous examples of iron application as a potential material for hydrogen storage or hydrogen production from carbonaceous materials are given, along with numerous problems reported, such as weak utilization of reducing gases $\left(\mathrm{H}_{2}, \mathrm{CO}\right.$ and $\left.\mathrm{CH}_{4}\right)$, carbon deposition and $\mathrm{Fe}_{3} \mathrm{C}$ formation. In the light of the above in the study presented, germanium was selected as potentially superior to iron.

The comparison of the potential performance of the $\mathrm{Fe}-\mathrm{Fe}_{3} \mathrm{O}_{4}$ loop and the double $\mathrm{Fe}-\mathrm{Fe}_{3} \mathrm{O}_{4} \mathrm{Ge}-\mathrm{GeO}_{2}$ loop in hydrogen storage and production, assessed on the basis of compositions of thermodynamically feasible gas mixtures applied and produced during the studied cycles is discussed below. 
Comparison of iron based loop and double iron and germanium based loop

The comparison was made for reactors of theoretical capacity of $100 \mathrm{~mol}$ of hydrogen during oxidation stage of the cycle. It is assumed that 100 vol. $\%$ hydrogen, carbon monoxide or methane is applied in the reduction stage and $100 \mathrm{vol} . \%$ steam in the oxidation stage. In case of using methane as a reducing agent, the pressure of $1 \mathrm{MPa}$ is considered. The hydrogen production process is assumed to be performed at $300{ }^{\circ} \mathrm{C}$, and the reduction at $800{ }^{\circ} \mathrm{C}$.

Hydrogen production in iron based loop - oxidation with steam

A reactor with the capacity of $100 \mathrm{~mol}$ of $\mathrm{H}_{2}$ contains $75 \mathrm{~mol}$ of $\mathrm{Fe}$. The amount of steam consumed in hydrogen generation is $103.92 \mathrm{~mol}$. The gas produced

Table 1. Fe reactor performance

\begin{tabular}{|c|c|c|c|}
\hline \multicolumn{4}{|c|}{ Fe reactor; the capacity of $100 \mathrm{~mol}$ of $\mathrm{H}_{2}$, containing $75 \mathrm{~mol}$ of $\mathrm{Fe}$} \\
\hline \multicolumn{4}{|c|}{ Hydrogen production / oxidation stage; $\mathrm{T}=300{ }^{\circ} \mathrm{C}$} \\
\hline & inlet gas & $\mathrm{H}_{2} \mathrm{O}$ & $103.92 \mathrm{~mol}(100.00$ vol. $\%)$ \\
\hline \multirow{2}{*}{\multicolumn{2}{|c|}{ outlet gas }} & $\mathrm{H}_{2}$ & $100.00 \mathrm{~mol}(96.23 \mathrm{vol} . \%)$ \\
\hline & & $\mathrm{H}_{2} \mathrm{O}$ & $3.92 \mathrm{~mol}(3.77 \mathrm{vol} . \%)$ \\
\hline \multicolumn{3}{|c|}{ reactor state } & $25.00 \mathrm{~mol}$ of $\mathrm{Fe}_{3} \mathrm{O}_{4}$ \\
\hline \multicolumn{4}{|c|}{ Reduction with $\mathrm{H}_{2}, \mathrm{~T}=800^{\circ} \mathrm{C}$} \\
\hline \multirow[t]{4}{*}{$\mathrm{Fe}_{3} \mathrm{O}_{4}$ to $\mathrm{Fe}_{0.947} \mathrm{O}$ stage } & inlet gas & $\mathrm{H}_{2}$ & $28.08 \mathrm{~mol}(100.00 \mathrm{vol} . \%)$ \\
\hline & outlet gas & $\mathrm{H}_{2}$ & $7.28 \mathrm{~mol}(25.93 \mathrm{vol} . \%)$ \\
\hline & & $\mathrm{H}_{2} \mathrm{O}$ & $20.80 \mathrm{~mol}(74.07 \mathrm{vol} . \%)$ \\
\hline & reactor state & $\mathrm{Fe}_{0.947} \mathrm{O}$ & $79.20 \mathrm{~mol}$ \\
\hline \multirow[t]{4}{*}{$\mathrm{Fe}_{0.947} \mathrm{O}$ to $\mathrm{Fe}$ stage } & inlet gas & $\mathrm{H}_{2}$ & $269.11 \mathrm{~mol}(100.00 \mathrm{vol} . \%)$ \\
\hline & outlet gas & $\mathrm{H}_{2}$ & $189.91 \mathrm{~mol}(70.57 \mathrm{vol} . \%)$ \\
\hline & & $\mathrm{H}_{2} \mathrm{O}$ & $79.20(29.43$ vol. $\%)$ \\
\hline & reactor state & $\mathrm{Fe}$ & $75.00 \mathrm{~mol}$ \\
\hline \multicolumn{2}{|l|}{ Total amount of pure $\mathrm{H}_{2}$ consumed } & & $297.19 \mathrm{~mol}$ \\
\hline \multicolumn{4}{|c|}{ Reduction with $\mathrm{CO}, \mathrm{T}=800^{\circ} \mathrm{C}$} \\
\hline \multirow[t]{4}{*}{$\mathrm{Fe}_{3} \mathrm{O}_{4}$ to $\mathrm{Fe}_{0.947} \mathrm{O}$ stage } & inlet gas & $\mathrm{CO}$ & $27.31(100.00$ vol. $\%)$ \\
\hline & outlet gas & $\mathrm{CO}$ & $6.51 \mathrm{~mol}(23.84$ vol. $\%)$ \\
\hline & & $\mathrm{CO}_{2}$ & $20.80 \mathrm{~mol}$ (76.16 vol.\%) \\
\hline & reactor state & $\mathrm{Fe}_{0.947} \mathrm{O}$ & $79.20 \mathrm{~mol}$ \\
\hline \multirow[t]{4}{*}{$\mathrm{Fe}_{0.947} \mathrm{O}$ to $\mathrm{Fe}$ stage } & inlet gas & $\mathrm{CO}$ & $248.90 \mathrm{~mol}(100.00 \mathrm{vol} . \%)$ \\
\hline & outlet gas & $\mathrm{CO}$ & $169.70 \mathrm{~mol}(68.18 \mathrm{vol} . \%)$ \\
\hline & & $\mathrm{CO}_{2}$ & $79.20 \mathrm{~mol}$ (31.82 vol.\%) \\
\hline & reactor state & $\mathrm{Fe}$ & $75 \mathrm{~mol}$ \\
\hline \multicolumn{2}{|l|}{ Total amount of pure $\mathrm{CO}$ consumed } & & $276.21 \mathrm{~mol}$ \\
\hline \multicolumn{4}{|c|}{ Reduction with $\mathrm{CH}_{4}, \mathrm{~T}=800{ }^{\circ} \mathrm{C}$} \\
\hline \multirow[t]{5}{*}{$\mathrm{Fe}_{3} \mathrm{O}_{4}$ to $\mathrm{Fe}_{0.947} \mathrm{O}$ stage } & inlet gas & $\mathrm{CH}_{4}$ & $5.202 \mathrm{~mol}(100.00 \mathrm{vol} . \%)$ \\
\hline & outlet gas & $\mathrm{CH}_{4}$ & $0.002 \mathrm{~mol}(0.01 \mathrm{vol} . \%)$ \\
\hline & & $\mathrm{CO}_{2}$ & $5.20 \mathrm{~mol}(33.33 \mathrm{vol} . \%)$ \\
\hline & & $\mathrm{H}_{2} \mathrm{O}$ & $10.40 \mathrm{~mol}(66.66 \mathrm{vol} . \%)$ \\
\hline & reactor state & $\mathrm{Fe}_{0.947} \mathrm{O}$ & $79.20 \mathrm{~mol}$ \\
\hline \multirow[t]{5}{*}{$\mathrm{Fe}_{0.947} \mathrm{O}$ to $\mathrm{Fe}$ stage } & inlet gas & $\mathrm{CH}_{4}$ & $67.66 \mathrm{~mol}(100.00 \mathrm{vol} . \%)$ \\
\hline & outlet gas & $\mathrm{CH}_{4}$ & $47.86 \mathrm{~mol}$ (44.62 vol.\%) \\
\hline & & $\mathrm{CO}_{2}$ & $19.80 \mathrm{~mol}(18.46 \mathrm{vol} . \%)$ \\
\hline & & $\mathrm{H}_{2} \mathrm{O}$ & $39.60 \mathrm{~mol}$ (36.92 vol.\%) \\
\hline & reactor state & $\mathrm{Fe}$ & $75.00 \mathrm{~mol}$ \\
\hline Total amount of pure $\mathrm{CH}_{4}$ consumed & & & $72.87 \mathrm{~mol}$ \\
\hline
\end{tabular}


consists of $100 \mathrm{~mol}$ of $\mathrm{H}_{2}(96.23 \mathrm{vol} . \%)$ and $3.92 \mathrm{~mol}$ of $\mathrm{H}_{2} \mathrm{O}$ (3.77 vol.\%). During the oxidation stage $25 \mathrm{~mol}$ of $\mathrm{Fe}_{3} \mathrm{O}_{4}$ is created. Table 1 summarizes the $\mathrm{Fe}$ reactor performance.

\section{Reduction with hydrogen in iron based loop}

In the first stage, $25 \mathrm{~mol}$ of $\mathrm{Fe}_{3} \mathrm{O}_{4}$ is reduced to wustite. The amount of $\mathrm{Fe}_{0.947} \mathrm{O}$ produced is $79.20 \mathrm{~mol}$. The amount of hydrogen consumed is $28.08 \mathrm{~mol}$. The composition of product gaseous mixture is: $\mathrm{H}_{2} \mathrm{O}: 20.80 \mathrm{~mol}(74.07 \mathrm{vol} . \%)$ and $\mathrm{H}_{2}: 7.28 \mathrm{~mol}$ (25.93 vol.\%). In the following step wustite is reduced to iron. The amount of iron produced is $75.00 \mathrm{~mol}$, the amount of hydrogen consumed is $269.11 \mathrm{~mol}$, and the composition of gas produced is: $\mathrm{H}_{2} \mathrm{O}: 79.20$ (29.43 vol.\%) and $\mathrm{H}_{2}: 189.91 \mathrm{~mol}(70.57$ vol.\%).

\section{Reduction with carbon monoxide in iron based loop}

$25 \mathrm{~mol}$ of $\mathrm{Fe}_{3} \mathrm{O}_{4}$ is reduced to 79.20 mol of wustite with $27.31 \mathrm{~mol}$ of $\mathrm{CO}$. The composition of the product gas is $20.80 \mathrm{~mol}$ (76.16 vol.\%) of $\mathrm{CO}_{2}$ and $6.51 \mathrm{~mol}$ (23.84 vol.\%) of CO. Next, $79.20 \mathrm{~mol}$ of wustite is reduced to $75.00 \mathrm{~mol}$ of Fe with $248.90 \mathrm{~mol}$ of $\mathrm{CO}$, and the resulting composition of the product gas is $79.20 \mathrm{~mol}$ (31.82 vol.\%) of $\mathrm{CO}_{2}$ and $169.70 \mathrm{~mol}(68.18 \mathrm{vol} . \%)$ of CO.

\section{Reduction with methane in iron based loop}

The reaction of $1 \mathrm{~mol}$ of methane with iron oxide creates $2 \mathrm{~mol}$ of $\mathrm{H}_{2} \mathrm{O}$ and $1 \mathrm{~mol}$ of $\mathrm{CO}_{2}$. Thus, the fraction of $\mathrm{CH}_{4}$ consumed during the reaction is correlated to the fraction of $\mathrm{CH}_{4}$ in an equilibrium gas according to the following equation:

$$
\begin{aligned}
\mathrm{X}_{\mathrm{CH}_{4} \text { consumed }} & =\frac{\left(\mathrm{X}_{\mathrm{H}_{2} \mathrm{O}}+\mathrm{X}_{\mathrm{CO}_{2}}\right) / 3}{\mathrm{X}_{\mathrm{CH}_{4}}+\left(\mathrm{X}_{\mathrm{H}_{2} \mathrm{O}}+\mathrm{X}_{\mathrm{CO}_{2}}\right) / 3}= \\
& =\frac{\left(1-\mathrm{X}_{\mathrm{CH}_{4}}\right) / 3}{\mathrm{X}_{\mathrm{CH}_{4}}+\left(1-\mathrm{X}_{\mathrm{CH}_{4}}\right) / 3}=\frac{1-\mathrm{X}_{\mathrm{CH}_{4}}}{1+2 \mathrm{X}_{\mathrm{CH}_{4}}}
\end{aligned}
$$

The calculation presented below is made for the pressure of $1 \mathrm{MPa} .25 \mathrm{~mol}$ of $\mathrm{Fe}_{3} \mathrm{O}_{4}$ is reduced to 79.20 mol of wustite. The amount of $\mathrm{CH}_{4}$ consumed is: $\frac{25}{4.807} / \frac{1-0.0001}{1+2 \times 0.0001}=5.202 \mathrm{~mol}$. The gas produced is composed of $0.01 \mathrm{~mol}$ of $\mathrm{CH}_{4}(0.01 \mathrm{vol} . \%), 5.20 \mathrm{~mol}$ of $\mathrm{CO}_{2}$ (33.33 vol.\%) and $10.40 \mathrm{~mol}$ of $\mathrm{H}_{2} \mathrm{O}$ (66.66 vol.\%). $79.20 \mathrm{~mol}$ of wustite is reduced to $75 \mathrm{~mol}$ of iron and the amount of $\mathrm{CH}_{4}$ consumed is $68.40 \mathrm{~mol}$. The resulting gas is composed of $47.86 \mathrm{~mol}$ of $\mathrm{CH}_{4}$ (44.62 vol.\%),
$19.80 \mathrm{~mol}$ of $\mathrm{CO}_{2}(18.46 \mathrm{vol} . \%)$ and $39.60 \mathrm{~mol}$ of $\mathrm{H}_{2} \mathrm{O}$ (36.92 vol.\%).

Iron and germanium based double loop

Iron and germanium reactor with the capacity of $100 \mathrm{~mol}$ of $\mathrm{H}_{2}$ contains $37.5 \mathrm{~mol}$ of $\mathrm{Fe}$ and $25 \mathrm{~mol}$ of Ge. Hydrogen is generated by blowing Fe bed with steam, and subsequently by blowing Ge bed with produced $\mathrm{H}_{2} / \mathrm{H}_{2} \mathrm{O}$ stream. Hydrogen is generated at the temperature of $300{ }^{\circ} \mathrm{C}$ and the reduction reaction is performed at $800{ }^{\circ} \mathrm{C}$. In case of methane, the pressure of $1 \mathrm{MPa}$ is considered. The schematic diagram of $\mathrm{Fe}-\mathrm{Ge}$ reactor performance is presented in Figure 4. Tables 2 and 3 summarize the $\mathrm{Fe}-\mathrm{Ge}$ reactor performance.

Hydrogen production in iron and germanium double loop

$37.5 \mathrm{~mol}$ of $\mathrm{Fe}$ is blown with $100.28 \mathrm{~mol}$ of $\mathrm{H}_{2} \mathrm{O}$ to generate $12.5 \mathrm{~mol}$ of $\mathrm{Fe}_{3} \mathrm{O}_{4}$. The product gas is composed of $50 \mathrm{~mol}$ of $\mathrm{H}_{2}$ and $50.28 \mathrm{~mol}$ of $\mathrm{H}_{2} \mathrm{O}$ (the reaction is limited by the availability of $\mathrm{Fe}$ ). This gaseous mixture reacts with $25 \mathrm{~mol}$ of Ge which results in $25 \mathrm{~mol}_{\text {of }} \mathrm{GeO}_{2}$ produced. The outlet gas is composed of $100 \mathrm{~mol}$ of $\mathrm{H}_{2}$ and $0.28 \mathrm{~mol}$ of $\mathrm{H}_{2} \mathrm{O}$.

Reduction with hydrogen in iron and germanium double loop

Magnetite is reduced with pure hydrogen to wustite and then to pure iron. The process is performed as described in Reduction with hydrogen in iron based loop sub-section. The compositions of the gas mixtures applied are similar, but the quantities are halved. The outlet gas from the $\mathrm{Fe}_{3} \mathrm{O}_{4} / \mathrm{Fe}_{0.947} \mathrm{O}$ stage is vented. $\mathrm{GeO}_{2}$ is reduced with the outlet gas from the $\mathrm{Fe}_{0.947} \mathrm{O}$ stage and some additional amount of hydrogen. The $\mathrm{Fe}_{0.947} \mathrm{O} / \mathrm{Fe}$ process gas contains $39.60 \mathrm{~mol}$ (29.43 vol.\%) of $\mathrm{H}_{2} \mathrm{O}$ and $94.96 \mathrm{~mol}$ (70.57 vol.\%)

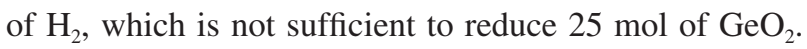
The outlet gas from Ge reactor should contain $89.60 \mathrm{~mol}$ of $\mathrm{H}_{2} \mathrm{O}$ (50 mol produced in $\mathrm{GeO}_{2}$ reduction). The outlet gas will also contain $71.00 \mathrm{~mol}$ of $\mathrm{H}_{2}(44.21 \mathrm{vol} . \%)$. The inlet gas composition would be $121.00 \mathrm{~mol}$ (75.34 vol.\%) of $\mathrm{H}_{2}$ and $39.60 \mathrm{~mol}$ (24.66 vol.\%) of $\mathrm{H}_{2} \mathrm{O}$ and the extra amount of $\mathrm{H}_{2}$ is $26.04 \mathrm{~mol}$.

Reduction with carbon monoxide in iron and germanium double loop

Magnetite is reduced with pure $\mathrm{CO}$ to wustite and then to pure iron in the process described in Reduction with carbon monoxide in iron based loop sub-section. 
Hydrogen production, $\mathrm{T}=300^{\circ} \mathrm{C}$

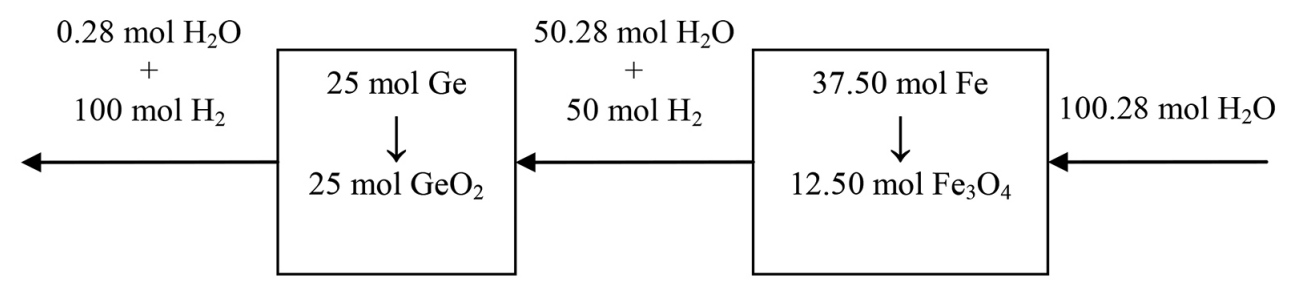

Reduction, $1^{\text {st }}$ stage, $\mathrm{T}=800{ }^{\circ} \mathrm{C}$
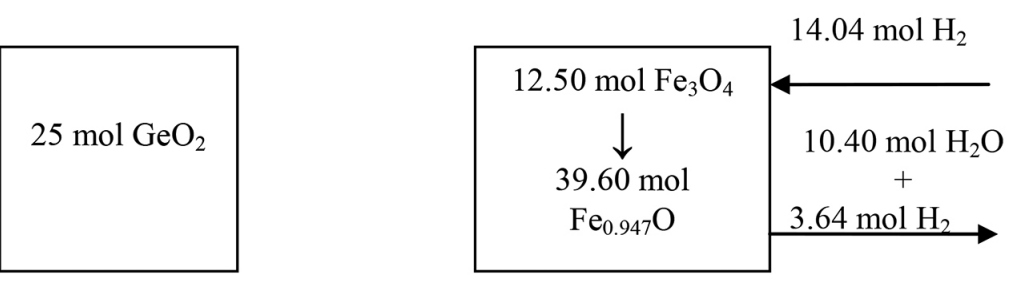

Reduction, $2^{\text {nd }}$ stage, $\mathrm{T}=800{ }^{\circ} \mathrm{C}$

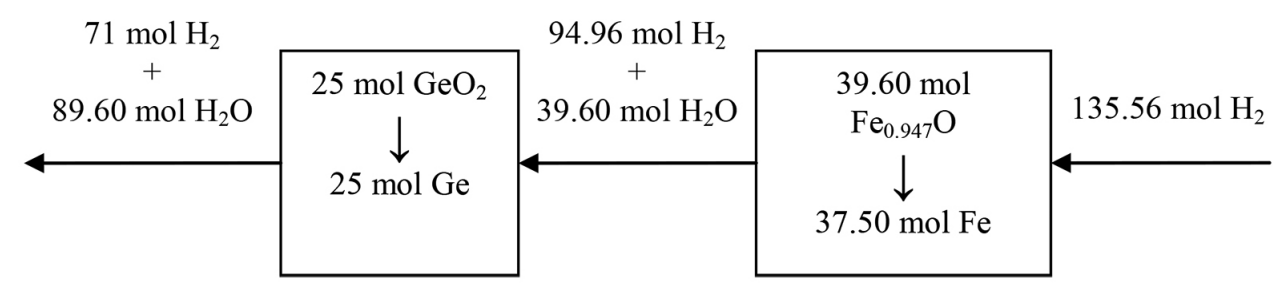

Figure 4. Schematic diagram of Fe-Ge reactor performance.

Table 2. The Fe-Ge reactor performance, hydrogen production

\begin{tabular}{|c|c|c|c|}
\hline \multicolumn{4}{|c|}{$\mathrm{Fe}-\mathrm{Ge}$ reactor; capacity of $100.00 \mathrm{~mol}$ of $\mathrm{H}_{2}$, containing $37.50 \mathrm{~mol}$ of $\mathrm{Fe}$ and $25.00 \mathrm{~mol}$ of Ge } \\
\hline \multicolumn{4}{|c|}{ Hydrogen production / oxidation stage; $\mathrm{T}=300^{\circ} \mathrm{C}$} \\
\hline \multirow[t]{4}{*}{ Fe reactor } & inlet gas & $\mathrm{H}_{2} \mathrm{O}$ & $100.28 \mathrm{~mol}(100.00 \mathrm{vol} . \%)$ \\
\hline & outlet gas/Ge reactor inlet gas & $\mathrm{H}_{2}$ & $50.00 \mathrm{~mol}(49.86$ vol.\%) \\
\hline & & $\mathrm{H}_{2} \mathrm{O}$ & $50.28 \mathrm{~mol}(50.14$ vol. $\%)$ \\
\hline & reactor state & & $12.50 \mathrm{~mol}$ of $\mathrm{Fe}_{3} \mathrm{O}_{4}$ \\
\hline \multirow[t]{3}{*}{ Ge reactor } & outlet gas & $\mathrm{H}_{2}$ & $100.00 \mathrm{~mol}$ (99.72 vol.\%) \\
\hline & & $\mathrm{H}_{2} \mathrm{O}$ & $0.28 \mathrm{~mol}(0.28 \mathrm{vol} . \%)$ \\
\hline & reactor state & $\mathrm{GeO}_{2}$ & $25.00 \mathrm{~mol}$ \\
\hline \multicolumn{4}{|c|}{ Reduction with $\mathrm{H}_{2}, \mathrm{~T}=800{ }^{\circ} \mathrm{C}$} \\
\hline \multirow[t]{4}{*}{$\mathrm{Fe}_{3} \mathrm{O}_{4}$ to $\mathrm{Fe}_{0.947} \mathrm{O}$ stage } & inlet gas & $\mathrm{H}_{2}$ & $14.04 \mathrm{~mol}(100.00 \mathrm{vol} . \%)$ \\
\hline & outlet gas & $\mathrm{H}_{2}$ & $3.64 \mathrm{~mol}(25.93$ vol. $\%)$ \\
\hline & & $\mathrm{H}_{2} \mathrm{O}$ & 10.40 mol (74.07 vol.\%) \\
\hline & reactor state & $\mathrm{Fe}_{0.947} \mathrm{O}$ & $39.60 \mathrm{~mol}$ \\
\hline \multirow[t]{4}{*}{$\mathrm{Fe}_{0.947} \mathrm{O}$ to $\mathrm{Fe}$ stage } & inlet gas & $\mathrm{H}_{2}$ & $134.56 \mathrm{~mol}$ (100.00 vol.\%) \\
\hline & outlet gas & $\mathrm{H}_{2}$ & 94.96 mol (70.57 vol.\%) \\
\hline & & $\mathrm{H}_{2} \mathrm{O}$ & $39.60(29.43$ vol. $\%)$ \\
\hline & reactor state & $\mathrm{Fe}$ & $37.50 \mathrm{~mol}$ \\
\hline \multirow{5}{*}{$\begin{array}{l}\text { Ge reactor } \\
\mathrm{GeO}_{2} \text { to } \mathrm{Ge}\end{array}$} & inlet gas & $\mathrm{H}_{2}$ & $121.00 \mathrm{~mol}(75.34 \mathrm{vol} . \%)$ \\
\hline & & $\mathrm{H}_{2} \mathrm{O}$ & $39.60 \mathrm{~mol}(24.66 \mathrm{vol} . \%)$ \\
\hline & outlet gas & $\mathrm{H}_{2}$ & $71.00 \mathrm{~mol}(44.21$ vol.\%) \\
\hline & & $\mathrm{H}_{2} \mathrm{O}$ & $89.60 \mathrm{~mol}(55.79 \mathrm{vol} . \%)$ \\
\hline & reactor state & $\mathrm{Ge}$ & $25.00 \mathrm{~mol}$ \\
\hline Total amount of pure $\mathrm{H}_{2}$ consumed & & & $174.64 \mathrm{~mol}$ \\
\hline
\end{tabular}


Table 3. The Fe-Ge rector performance, reduction with methane

\begin{tabular}{|c|c|c|c|}
\hline \multicolumn{4}{|c|}{ Fe-Ge reactor; capacity of $100.00 \mathrm{~mol}$ of $\mathrm{H}_{2}$, containing $37.50 \mathrm{~mol}$ of $\mathrm{Fe}$ and $25.00 \mathrm{~mol}$ of Ge } \\
\hline \multicolumn{4}{|c|}{ Reduction with $\mathrm{CO}, \mathrm{T}=800^{\circ} \mathrm{C}$} \\
\hline \multirow[t]{4}{*}{$\mathrm{Fe}_{3} \mathrm{O}_{4}$ to $\mathrm{Fe}_{0.947} \mathrm{O}$ stage } & inlet gas & $\mathrm{CO}$ & $13.64 \mathrm{~mol}(100.00 \mathrm{vol} . \%)$ \\
\hline & outlet gas & $\mathrm{CO}$ & $3.25 \mathrm{~mol}(23.83 \mathrm{vol} . \%)$ \\
\hline & & $\mathrm{CO}_{2}$ & $10.39 \mathrm{~mol}(76.17 \mathrm{vol} . \%)$ \\
\hline & reactor state & $\mathrm{Fe}_{0.947} \mathrm{O}$ & $39.10 \mathrm{~mol}$ \\
\hline \multirow[t]{4}{*}{$\mathrm{Fe}_{0.947} \mathrm{O}$ to $\mathrm{Fe}$ stage } & inlet gas & $\mathrm{CO}$ & $123.95 \mathrm{~mol}(100.00 \mathrm{vol} . \%)$ \\
\hline & outlet gas & $\mathrm{CO}$ & $84.85 \mathrm{~mol}(68.46 \mathrm{vol} . \%)$ \\
\hline & & $\mathrm{CO}_{2}$ & $39.10 \mathrm{~mol}(31.54$ vol. $\%)$ \\
\hline & reactor state & $\mathrm{Fe}$ & $37.50 \mathrm{~mol}$ \\
\hline \multirow{5}{*}{$\begin{array}{l}\text { Ge reactor } \\
\mathrm{GeO}_{2} \text { to } \mathrm{Ge}\end{array}$} & inlet gas & $\mathrm{CO}$ & $115.12 \mathrm{~mol}$ (74.41 vol.\%) \\
\hline & & $\mathrm{CO}_{2}$ & $39.52 \mathrm{~mol}$ (25.59 vol.\%) \\
\hline & outlet gas & $\mathrm{CO}$ & $65.12 \mathrm{~mol}$ (42.09 vol.\%) \\
\hline & & $\mathrm{CO}_{2}$ & $89.60 \mathrm{~mol}$ (57.91 vol.\% ) \\
\hline & reactor state & $\mathrm{Ge}$ & $25.00 \mathrm{~mol}$ \\
\hline \multicolumn{2}{|l|}{ Total amount of pure $\mathrm{CO}$ consumed } & & $168.37 \mathrm{~mol}$ \\
\hline \multicolumn{4}{|c|}{ Reduction with $\mathrm{CH}_{4}, \mathrm{~T}=800^{\circ} \mathrm{C}$} \\
\hline \multirow{5}{*}{$\begin{array}{l}\mathrm{Fe} \text { reactor } \\
\mathrm{Fe}_{3} \mathrm{O}_{4} \text { to } \mathrm{Fe}_{0.947} \mathrm{O} \text { stage }\end{array}$} & inlet gas & $\mathrm{CH}_{4}$ & $2.61 \mathrm{~mol}(100 \mathrm{vol} . \%)$ \\
\hline & outlet gas & $\mathrm{CH}_{4}$ & $0.01 \mathrm{~mol}(0.13 \mathrm{vol} . \%)$ \\
\hline & & $\mathrm{CO}_{2}$ & $2.60 \mathrm{~mol}$ (33.29 vol.\%) \\
\hline & & $\mathrm{H}_{2} \mathrm{O}$ & $5.20 \mathrm{~mol}(66.58 \mathrm{vol} . \%)$ \\
\hline & reactor state & $\mathrm{Fe}_{0.947} \mathrm{O}$ & $39.60 \mathrm{~mol}$ \\
\hline \multirow{5}{*}{$\begin{array}{l}\mathrm{Fe} \text { reactor } \\
\mathrm{Fe}_{0.947} \mathrm{O} \text { to } \mathrm{Fe} \text { stage }\end{array}$} & inlet gas & $\mathrm{CH}_{4}$ & $33.53 \mathrm{~mol}(100 \mathrm{vol} . \%)$ \\
\hline & outlet gas/Ge reactor inlet gas & $\mathrm{CH}_{4}$ & $23.93 \mathrm{~mol}$ (44.62 vol.\%) \\
\hline & & $\mathrm{CO}_{2}$ & 9.90 mol (18.46 vol.\%) \\
\hline & & $\mathrm{H}_{2} \mathrm{O}$ & $19.80 \mathrm{~mol}(36.92$ vol. $\%)$ \\
\hline & reactor state & $\mathrm{Fe}$ & $37.50 \mathrm{~mol}$ \\
\hline \multirow{4}{*}{$\begin{array}{l}\text { Ge reactor } \\
\mathrm{GeO}_{2} \text { to } \mathrm{Ge} \text { stage }\end{array}$} & outlet gas & $\mathrm{CH}_{4}$ & $11.40 \mathrm{~mol}$ (14.50 vol.\%) \\
\hline & & $\mathrm{CO}_{2}$ & $22.40 \mathrm{~mol}$ (28.50 vol.\%) \\
\hline & & $\mathrm{H}_{2} \mathrm{O}$ & $44.80 \mathrm{~mol}(57.00 \mathrm{vol} . \%)$ \\
\hline & reactor state & $\mathrm{Ge}$ & $25.00 \mathrm{~mol}$ \\
\hline Total amount of pure $\mathrm{CH}_{4}$ consumed & & & $36.43 \mathrm{~mol}$ \\
\hline
\end{tabular}

The composition of gaseous reactants applied are similar, while their quantities are halved. The $\mathrm{Fe}_{3} \mathrm{O}_{4} / \mathrm{Fe}_{0.947} \mathrm{O}$ stage outlet gas is vented. $\mathrm{GeO}_{2}$ is reduced with the outlet gas from the $\mathrm{Fe}_{0.947} \mathrm{O}$ stage and some additional amount of CO. The $\mathrm{Fe}_{0.947} \mathrm{O} / \mathrm{Fe}$ process outlet gas contains $84.85 \mathrm{~mol}$ (68.46 vol.\%) of $\mathrm{CO}$ and $39.10 \mathrm{~mol}$ (31.54 vol.\%) of $\mathrm{CO}_{2}$. The amount of $\mathrm{CO}$ is too low for the reduction of $25 \mathrm{~mol}$ of $\mathrm{GeO}_{2}$. The outlet gas from $\mathrm{Ge}$ reactor would contain 89.60 mol of $\mathrm{CO}_{2}$ (50 mol produced in $\mathrm{GeO}_{2}$ reduction) and $65.12 \mathrm{~mol}$ (42.09 vol.\%) of CO. The inlet gas composition should be as follows: $115.12 \mathrm{~mol}$ (74.41 vol.\%) of CO and $39.60 \mathrm{~mol}(25.59 \mathrm{vol} . \%)$ of $\mathrm{CO}_{2}$ and the amount of extra $\mathrm{CO}$ is $30.27 \mathrm{~mol}$.

\section{Reduction with methane in iron and germanium double loop}

Magnetite is reduced with pure $\mathrm{CH}_{4}$ to wustite and then to pure iron in the process described in Reduction with methane in iron based loop sub-section. The composition of gases employed are similar and their amounts are halved. The $\mathrm{Fe}_{3} \mathrm{O}_{4} / \mathrm{Fe}_{0.947} \mathrm{O}$ stage outlet gas is vented. $\mathrm{GeO}_{2}$ is reduced with the outlet gas from the $\mathrm{Fe}_{0.947} \mathrm{O}$ stage. The $\mathrm{Fe}_{0.947} \mathrm{O} / \mathrm{Fe}$ process outlet gas contains $23.93 \mathrm{~mol}$ of $\mathrm{CH}_{4}$ (44.62 vol.\%), $9.90 \mathrm{~mol}$ of $\mathrm{CO}_{2}$ (18.46 vol.\%) and $19.80 \mathrm{~mol}$ of $\mathrm{H}_{2} \mathrm{O}$ (36.92 vol.\%). The amount of $\mathrm{CH}_{4}$ is sufficient to reduce $25 \mathrm{~mol}$ of $\mathrm{GeO}_{2}$. The Ge reactor outlet gas would contain $22.40 \mathrm{~mol}$ of $\mathrm{CO}_{2}, 44.80 \mathrm{~mol}$ of $\mathrm{H}_{2} \mathrm{O}$ (12.5 mol of $\mathrm{CO}_{2}$ and $25 \mathrm{~mol}$ of $\mathrm{H}_{2} \mathrm{O}$ are produced in $\mathrm{GeO}_{2}$ reduction) and $11.4 \mathrm{~mol}$ of $\mathrm{CH}_{4}\left(12.5 \mathrm{~mol}\right.$ of $\mathrm{CH}_{4}$ is consumed). The methane content in gas is still higher than in the equilibrium atmosphere. The percentage composition of the outlet gas is: $14.50 \mathrm{vol} . \%$ of $\mathrm{CH}_{4}, 28.50 \mathrm{vol} . \%$ of $\mathrm{CO}_{2}$ and 57.00 vol. $\%$ of $\mathrm{H}_{2} \mathrm{O}$.

\section{Conclusions}

The LTSI process may be applied in hydrogen production and storage. The thermodynamic calculations 
show that the reducing stage of the process may be problematic, since the reaction achieves equilibrium state when there is still a large fraction of the reducing gas (hydrogen, carbon monoxide or methane) present in the reaction atmosphere. The computations presented also indicate that the combination of iron and germanium loops may be an interesting option for the steam-iron process in a solid phase at temperatures below $1000^{\circ} \mathrm{C}$. In such a double cycle, the outlet gas contains a significantly smaller fraction of the reducing gas, since smaller quantity of the reducing gas needs to be used. For the double Fe-Ge loop a decrease of approximately $58.76,60.96$ and $49.99 \%$ for the reducing gases like $\mathrm{H}_{2}, \mathrm{CO}$ and $\mathrm{CH}_{4}$ is reported, respectively.

\section{Acknowledgments}

This work was supported by the Ministry of Science and Higher Education, Poland, under Grant No. 11310046.

\section{References}

1. Ball, M.; Weeda, M.; Int. J. Hydrogen Energy 2015, 40, 7903.

2. Maroufmashat, A.; Fowler, M.; Khavas, S. S.; Elkamel, A.; Roshandel, R.; Hajimiragha, A.; Int. J. Hydrogen Energy 2016, 41, 7700 .

3. Acha, E.; Requies, J.; Güemez, M. B.; Barrio, V. L.; Cambra, J. F.; Ariasm P. L.; Int. J. Hydrogen Energy 2014, 39, 5257.

4. Cormos, C. C.; Int. J. Hydrogen Energy 2010, 35, 2278.

5. Lorente, E.; Peña, J. A.; Herguido, J.; J. Power Sources 2009 , 192, 224.
6. Wang, H.; Liu, X.; Wen, F.; Int. J. Hydrogen Energy 2012, 37, 977.

7. Kathe, M. V.; Empfieldm, A.; Na, J.; Blair, E.; Fan, L. S.; Appl. Energy 2016, 165, 183.

8. Gupta, R. B.; Hydrogen Fuel. Production, Transport and Storage; CRC Press Taylor \& Francis Group: Boca Raton, USA, 2009.

9. Hacker, V.; Fankhauser, R.; Faleschini, G.; Fuchs, H.; Friedrich, K.; Muhr, M.; Kordesch, K.; J. Power Sources 2000, 86, 531.

10. Hacker, V.; J. Power Sources 2003, 118, 311.

11. Otsuka, K.; Kaburagi, T.; Yamada, C.; Takenaka, S.; J. Power Sources 2003, 122, 111.

12. Kosaka, F.; Hatano, H.; Oshima, Y.; Otomo, J.; Chem. Eng. Sci. 2015, 123, 380.

13. Choa, W. C.; Seo, M. W.; Kim, S. D.; Kang, K. S.; Bae, K. K.; Kim, C. H.; Jeong, S. U.; Park, C. S.; Int. J. Hydrogen Energy 2012, 37, 16852.

14. Otsuka, K.; Takenaka, S.; J. Jpn. Pet. Inst. 2004, 47, 377.

15. Datta, P.; Rihko-Struckmann, L. K.; Sundmacher, K.; Fuel Process. Technol. 2014, 128, 36.

16. Datta, P.; Rihko-Struckmann, L. K.; Sundmacher, K.; Mater. Chem. Phys. 2011, 129, 1089.

17. Urasaki, K.; Tanimoto, N.; Hayashi, T.; Sekine, Y.; Kikuchi, E.; Matsukata, M.; Appl. Catal., A 2005, 288, 143.

18. Svoboda, K.; Słowiński, G.; Rogut, J.; Baxter, D.; Energy Convers. Manage. 2007, 48, 3063.

Submitted: July 26, 2016

Published online: September 29, 2016 